\title{
Sinemada Temsil Kurmak: Mustang (2015) Filmi Üzerine Bir İnceleme
}

\author{
Zehra Cerrahoğlu*
}

$\ddot{O} z e t$

Türkiye kökenli yönetmen Deniz Gamze Ergüven'in ilk filmi Mustang (2015), Türkiye kırsalında tutucu büyükanneleri ve dayılar ile yaşayan beş kız kardeşin karşılaştı̆̆ baskı ve direnişlerini konu almaktadır. Bir Fransa, Almanya, Türkiye ve Katar ortak yapımı olan Mustang, Fransa'da yakaladığ 1 gişe başarısının yanında dört César'la ödüllendirilmiş; Fransa'nın 2015 Oscar adayı olmuştur. Filme getirilen temel eleştiriler arasında gerçeklikten uzak tasvirler, konuya yüzeysel yaklaşım, oryantalizm ve genç bedenlerin teşhiri yer almaktadır.

Filmlerde nelerin, nasıl temsil edildiği, yönetmenin bakış açısı ve yorumu, kullanılan klişeler ve ortaya çıkan söylem gibi konular yıllardır farklı biçimlerde tartışılmaktadır. Bu tartışmalara (bir sanat eseri olarak) filmin üretildiği ve temsilini kurmayı amaçladığı dönem, kültür ve toplumsal yapı da eklendiğinde denklemin bileşenleri artar.

Mustang'de, ele alınan konu küreselleştirilmeye çalışılırken yerelleştirilmekte; bu da 'kırsaldaki genç kadınların' temsiline yabancı bir bakışla yapılmaktadır. Bu söylem analizi denemesinde, film özelinde hem sinemanın temsil kurma stratejilerinin 'nasıl temsillerle' 'etnikleştirme'ye yol açabileceği hem de 'kime ait (yerel/küresel) temsiller kurulduğ $u^{\prime}$ sorularının yanıtı aranacaktır.

Anahtar kelimeler: sinemada temsil, Mustang, oto-etnografi

ORCID ID : 0000-0001-6528-0451

E-mail : zehracerrahoglu@gmail.com

DOI: $10.31122 /$ sinefilozofi.515253

Geliş Tarihi - Recieved: 20.01.2019

Kabul Tarihi - Accepted: 25.04.2019 


\title{
Forming a Representation: An Analysis on Mustang (2015)
}

\author{
Zehra Cerrahoğlu*
}

\begin{abstract}
Deniz Gamze Ergüven, a French director of Turkish origin, tells the story of five sisters living in the rural Turkey with their oppressive grandmother and uncle, and sisters' resistance to be oppressed in her first feature Mustang (2015). A France, Germany, Turkey and Qatar co-production, Mustang, has been awarded with four César Awards and has been French film nominee of 2015 Oscars, along with the box office success in France. On the other hand, film was criticized in Turkey with its unrealistic portrayals, superficial approaches to its subject matters, with orientalism and display of the bodies of young actors.

There had always been ongoing debates on what to represent and how to represent, clichés in films, point of view and interpretations of the director that reflects in their films, and the final discourse. These parameters advance as the period of the work of art, the period to be represented and social and cultural settings are added.

Mustang turns out as a film that its subject is localized while trying to be globalized, yet the film still stays as a foreigner to the representation of 'young women in rural town'. The main purposes of this discourse analyze attempt are investigating how the 'representational strategies of film' may lead to 'ethnicism' and discussing 'whose representation (local/global)' this is.
\end{abstract}

Keywords: representations in film, Mustang, auto-ethnography

ORCID ID : 0000-0001-6528-0451

E-mail : zehracerrahoglu@gmail.com

DOI: $10.31122 /$ sinefilozofi.515253

Recieved - Geliş Tarihi: 20.01.2019

Accepted - Kabul Tarihi: 25.04.2019 


\section{Giriş}

Sinemada temsillerin nasıl oluşturulduğu konusuna felsefe (estetik), sosyoloji ve siyaset bilimi gibi birçok alandan yaklaşmak mümkündür ve farklı alanlardan yorumlama örnekleri sayısız film incelemesinde yerini almıştır. Bu çalışmanın temel amacı ise gerçeklikle ilişkisi bakımından filmsel temsile eğilmek ve filmsel temsil ile yönetmenin yaptığı içerik ve biçime ait tercihlerin filmin üretim şekli ve süreciyle (Avrupa ortak yapım şeması ve film festivalleri) ilgisini kurmak olacaktır.

Çalışma alanımın odağını oluşturan konu filmsel üslup olduğundan, yöntemim felsefenin ya da sosyolojinin alanına müdahale etmekten çok sinemasal tercihlerin temsili nasıl ortaya çıkardığını açıklamaya çalışmak olacaktır. Böylece Mustang filmi üzerinden, bir filmde ortaya çıan temsillerin ve söylemlerin sunum mekanizmalarını detaylandırmaya çalışacağım.

Bu çerçevede izlenecek yol, önce sinemada temsil meselesine kısaca değinildikten ve özellikle gerçeklik-temsil ilişkisi üzerinde durulduktan sonra; bir ortak yapım olarak Mustang filmi özelinde tespit edilebilen temsil sorunları kapsamında eğilmek olacaktır. Son olarak da, kurulan temsilin kaynağı, yaratıcısı ve sahipliği konuları tartışmaya açılacaktır.

\section{Sinemada Temsil}

\section{Temsil Kavramı}

Temsil üzerine düşünülmeye mimesis (taklit) kavramı ile başlanmış ve sonrasında klasikten en soyutlamacı ve güncel anlayışlara kadar sanatsal yaratımın her türlüsünde tartışma konusu olarak güncelliğini korumuştur.

Stuart Hall'un Shorter Oxford English Dictionary' den aktarımıla temsil (representation) tanımları şöyledir:

1. Bir şeyi temsil etmek onu betimlemek ya da resmetmek, bu betimleme, ifade ya da imgelem aracılı̆̆ıla zihinde canlanmasını să̆lamak; zihnimiz ya da duyularımızda bir tasvir oluşturmaktır. Örnek: Bu resim Habil'in Kabil tarafindan öldürülüşünü temsil eder.

2. Temsil etme aynı zamanda sembolize etme, yerine geçme, simgeleme ya da yerini tutma anlamlarna da gelir. Örnek: Hristiyanlıkta haç İsa'nın çilesini ve çarmıha gerilişini temsil eder(Hall, 1997:16).

Bu tanımlardan da anlaşılabileceği üzere sanatsal olsun ya da olmasın her türlü temsilde mevcut olanın, ya da kabul edilenin yerini tutma, onu ifade etme ve zihinde canlandırma söz konusudur.

Stuart Hall'un kendi tanımıla;

Temsil, kavramların anlamını zihnimizde dil aracıllğıyla üretmektir. Nesnelerin, kişilerin ve olaylarn 'gerçek' dünyasından mı yoksa aslında kurmaca nesneler, kişiler ya da olaylardan mı söz ediyor olduğumuzu belirleyen şey, kavramlar ve dil arasındaki bağlantıdır(Hall, 1997:17).

Noël Carroll'ın sanatlarda temsil, biçim, içerik ve estetik eğilimler üzerine yazdığı Sanat Felsefesi, Çağdaş Bir Giriş kitabındaki en genel tanımı ise; 
Genel anlamda konuşursak, 'temsil' derken, ancak ve ancak (1) bir gönderici x'in (örneğin resim) bir şeyin yerine geçmesini amaçlarsa ve (2) bir izleyen x'in y'nin yerine geçmek için yapıldı̆̆ını fark ederse, $\mathrm{x}, \mathrm{y}^{\prime} \mathrm{yi}$ temsil eder diyebiliyoruz ( $\mathrm{y}$ nesneler, insanlar, olaylar ya da eylemler olabilir)(Carroll, 2012:79).

Temsil önce temsili oluşturanın zihninde, sonra da aktarım yöntemi aracılığıyla onu alımlayanların zihinlerinde şekillenir. Üretiminden yorumlanmasına kadar her aşamasında bulduğu karşılıklar değişiklik gösterebilir.

\section{Sanatsal üretimin genel tartışması; mimesis - taklit}

Temsil kavramının öncül bir biçimi gibi kullanılan ve temeli Platon ve Aristoteles'e dayanan mimesis, doğa ve insan eylemlerinin doğrudan taklidi olarak karşımıza çıkmaktadır. Aristoteles mimesis ${ }^{1}{ }^{\prime} i$ Poetika eserinde ele aldığı tragedya üzerinden tartışmaya başlamış ve böylece bugün yeniden üretim, sunum ve temsil üzerine söylediğimiz her şeyin tohumunu atmıştır. Tragedyada taklidi oluşturan öykü evreni üzerine, temsile ve söyleme giden yolu açan şu saptamalarda bulunmuştur:

4.Tragedya bir eylemin taklididir. Bu eylem, karakter ve düşünce bakımından belli bir özellikte olması gereken eylem halindeki kişilerce temsil edildiğine göre, -çünkü, bu iki etkenle eylemler belli bir özellik kazanırlar-, o halde karakter ve düşünce, tragik eylemin iki etkeni olarak ortaya çıkar; (...)

5.O halde, bir eylemin taklidi, öykü'dür(mythos). Öykü deyince, olayların örgüsünü; karakter deyince, eylemde bulunan kişilere kendisi bakımından bir özellik yorduğumuz şeyi; düşünce deyince de kendisiyle konuşanların bir şey kanttladığı ya da genel bir hakikate ifade verdikleri şeyi anliyorum(Aristoteles, 2012: 23).

İlkel toplumlarda iş ve av dansları, şarkıları, resimsel ifade ve bezemeleri ile insan hayatına doğrudan ritüel işlevlerle (bereket, büyü, kötülükleri bertaraf etmek, iyi şans vb.) kutsalın alanından giren temsil; gündelik kullanım alanından sanatın alanına geçiş yaparak sanatsal temsili oluşturmuştur. Taklit etme ve yansıtma araçlarının kullanımı kültürün ve inanç biçimlerinin olduğu kadar sanatın da tarihsel gelişimiyle birlikte değişim göstermiştir. Kilise etkisindeki dini resimden sanatçı üsluplarına, atölyelere, oradan da giderek soyutlamaya kayan plastik sanatlara, çağdaş/kavramsal sanata ve hatta hiper-gerçekçiliğe kadar giden aşamalarla sanatta temsil biçimleri değişmiştir. Temsil anlayışının günümüzdeki halini almasında fotoğraf ve sinemanın hayatımıza girişinin de önemli payı vardır.

\section{Temsilin Sinemadaki Karşılı̆̆1}

Gregory Currie, Image and Mind: Film, Philosophy and Cognitive Science başlıklı kitabında temsil konusundaki genel yaklaşımını; “Temsiller dünyadaki şeylere epistemik erişimimizi genişletir. Eğer güvenilirlerse, o şeylere erişimimiz olmasa bile bize onların bilgisini verebilirler" (Currie, 1995:49) şeklinde açıklamıştır.

1 İsmail Tunalı Poetika çevirisinin dizininde kavramı şöyle açıklamaktadır: “Bu deyim, Poetika'nın temel kavramlarından biri olup, antik estetiği karakterize eder. Aristoteles, mimesis (taklit) deyince, bir real objenin taklidini değil de, idealize edici bir faaliyeti kasteder." (Aristoteles, 2012: 102) 
Hareketli görüntünün hem teknolojik hem de fotografik doğası gereği sahip olduğu ya da kazandığı düşünülen özellikleri ve zaman içerisinde kendine has görsel (ve işitsel) anlatılar kurabilmesiyle temsil, içerik ve biçim bazında da çokça ele alınmıştır. Bu noktada farklı bazı kavramlar karşımıza çıkmaktadır. Yeniden üretim (reproduction) kavramı, sinemanın teknik doğası ${ }^{2}$ gereği sahip olduğu bir özelliktir. Gerçekliğin yeniden üretimi ondan önce resim sanatının alanına ait kabul edilirken; fotoğraf makinesinin icadıyla plastik sanatlardaki gerçekçilik anlayışı ve onu yansıtma ihtiyacı ve şekilleri değişmiştir.

Elbette konunun kurmaca anlatı üzerinden de tartışılabilecek yönleri bulunmaktadır. Sunum (presentation) kavramı, sinemanın ifade aracı olma niteliğiyle ilintilidir. Currie'nin ifadesiyle teknik anlamda “Lensler çıplak gözle göremeyeceğimiz detayları görmemizi sağlar. Bize dünyayı temsil etmez (represent), sunarlar (present)"(Currie, 1995:50). Sinemadaki haliyle temsil (representation) ise sinemasal araçlar kullanılarak referans alınan her ne ise onun yerini tutacak başka ifadeler oluşturmak şeklinde tanımlanabilir. Kurulan bu ifadeler aracılığıyla ortaya çıkan nihai söz ya da yargı ise söylem kavramı ile karşılık bulmaktadır.

Söylem kavramı üzerine yapılan çalışmaların ilk akla getirdiği film kuramcısı, Saussure ve onun dilbilim üzerine çalışmalarından hareketle oluşturduğu sinema göstergebilimiyle tanınan Christian Metz'dir. Metz filmleri birer metin gibi değerlendirerek onları iç birimleri aracılığıyla analiz ettiği bir yöntem geliştirmiştir. Filmlerdeki söylemi (discourse) açıklama yolu parça-bütün ilişkisiyle sinemanın gramerini ortaya çıkararak, biçimsel bir yöntemle deşifre etmektir. ${ }^{3}$

Öykü ve Söylem, Filmde ve Kurmacada Anlatı Yapısı başlıklı kitabında Seymour Chatman söyleme yine biçimci bir bakış açısıyla yaklaşarak “ Anlatının ne'si, onun 'öykü'südür,

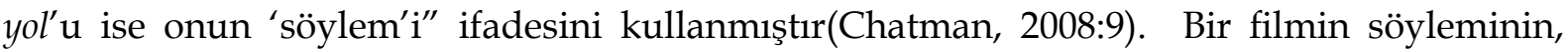
filmde ele alınan konular kadar onların filmde nasıl, hangi yöntem ve araçlarla ele alındığı ile de sıkı bir ilişkisi vardır.

Bir filmde yer alan temsilleri incelerken göz ardı edilmemesi gereken başlıca unsurlar arasinda;

- $\quad$ Neyin temsil edildiği,

- $\quad$ Temsillerin nasıl kurulduğu; filmin anlatımında hem görsel-işitsel hem de anlatıya dayalı araçlarla nasıl karşılık bulduğu,

- Temsili oluşturanların kim (ya da kimler) olduğu,

- Bu temsilin nasıl bir tarihsel dönemde oluşturulduğu,

- $\quad$ Kurulan temsilin ne ölçüde ve hangi klişelere dayandığı sorularına verilecek cevaplar bulunmaktadir.

2 Teknik yeniden üretim ve sanat eseri konusunda ayrıntılı bilgi için; Walter Benjamin, Tekniğin Olanaklarıyla Yeniden Üretilebildiği Çağda Sanat Yapıtı, Pasajlar, Yapı Kredi Yayınları, İstanbul: 2008.

3 Ayrıntılı bilgi için Bkz: Christian Metz, Sinemada Anlam Üstüne Denemeler, çev: Oğuz Adanır, Hayalperest Yayınevi, İstanbul: 2012. 
Filmde neyin ya da nelerin temsil ediliyor olduğu, filmin temasiyla ve konusuyla da birlikte düşünülmesi gereken, öncelikle içeriğe ait bir tartışmadır. Bu temsillerin nasıl kurulmuş olduğu ise biçim ve içerikle birlikte şekillenen, filmsel anlatım araçlarının nasıl kullanıldığı, öykünün nasıl bir olay örgüsü kurgusuyla oluşturulduğu ve film için özel olarak tasarlanan görsel-işitsel yöntemlerin amaca uygun şekilde nasıl kullanıldı̆̆ını ifade eder.

Temsili oluşturanların kimliği, onun yaratıcılarının kimliği (ülkesi, kökeni, eğilimleri vb.), gerek çağlardır sanat estetiğinin gerekse auteur sinemasının konularından biri olan sanatçının süzgecine ilişkin tartışmaların alanıdır.

Filmde kurulan temsillerin hangi dönemde oluşturulduğu da, içinde bulunulan ülkeye, filmin yapıldığı koşullara ve yıllara göre farklı hassasiyetlere sebebiyet verebilecek; sansür ya da oto-sansüre yol açabilecek şekillerde değişiklik gösterebilmektedir. Filmlerin yaratıcıları ve üreticileri tarihsel ve toplumsal koşullardan ayrı düşünülemezler.

Temsile ilişkin bir diğer kıstas da klişelerin kullanımına yöneliktir. Tıpkı öyküler, romanlar ve tiyatro oyunları gibi tüm kurmaca anlatılarda olduğu kadar sinemada da anlaşılır olabilmenin yolu klişelerin yerli yerinde kullanımından geçer. Ortalama iki saat süre içerisinde hem belli başlı karakterlere vakıf olup hem de onların diğerleri ile ilişkilerini, içinde bulundukları evreni ve yaşadıkları olayları tanımak ve anlamlandırabilmek için olaylar ve karakterler özelinde bazı klişelerin kullanılması kaçınılmazdır. Bazı karakterlerin kestirme yoldan daha iyi ya da daha kötü gösterilmesi gibi çözümler gerekebilir. Bu klişelerin filmsel evrende işleyebilmesi için karakterlerin belli şekillerde davranması ve başlarına gelecek olayların kabul edilebilir olması gerekir. Mustang' den örnekle; yaşamını Anadolu'da geçirmiş ellili yaşlarında kadınlardan ve uzun yıllarını bir kasabada geçiren genç kızlardan belli davranış kalıplarına sahip olması beklenir.

Temsile referans alınan gerçeklik üzerinden yapılan yorumlamalarla ulaşılır. Sanatçının gerçekliği ait olduğu dönem, kültür, yöntem ve araçlarıyla yorumlaması sonucu izleyiciye ulaşan temsil ortaya çıkmaktadır. Bu süreç temsili oluşturanın olduğu kadar, onu algılayanın da katılımını gerektiren bir yorumlama sürecidir. İzleyici olarak bizler kendi bilgilerimiz ve geçmiş deneyimlerimize dayanarak belli yargılara varabiliriz. Casebier'in filmsel temsil konusundaki yorumu ile:

İzleyici film denen şeyin dışında tutulamaz, ondaki temsilleri ve diğer özellikleri kavrayarak güncel tabirle, tıpkı metnin yaratımındaki aktif katılımcilar kadar metne dahil olur. Dahası, bu aktivitelerinde metinlerdeki anlam ve temsillerin oluşturulmasında kullanılan kodları kullanırlar. Bu kodlar arasında sinemasal kodlar, kültürel kodlar, sinemactnın kendi kodları gibi şeyler bulunmaktadır(Casebier, 1991:47).

Hiç bir filmsel temsil rastlantısal değildir. Senaryo aşamasından post-prodüksiyonun son aşamalarına kadar filmler birçok değerlendirmeden geçer ve nihai anlamda yaratıcılarının söylemek istediklerini içerirler. Temel referansın somut gerçeklik olduğu en gerçekçi film anlayışlarında bile, anlatısal ve görsel-işitsel stratejilere dayanan tercihler bazı unsurları ön plana taşırken diğerlerini geriye iter ve aralarında hiyerarşiye dayanan bir seçim yapar. Bu bağlamda, ortaya çıan temsil ve söylemin rastlantısal olduğunu düşünmek zordur. 


\section{Sinemada Gerçeklik-Temsil İlişkisi}

Konu çerçevesinde değerlendirilebilecek en önemli tartışmalar, mimesis kavramının da çıkış noktasını oluşturduğu gerçeklik - temsil ilişkisi olmuştur. Birçok film kuramcısı gerçeklik konusunu farklı boyutlarıyla tartışmakla birlikte en çok başvurulan yaklaşımlardan biri André Bazin'e aittir. Sinemanın gerçeklikle bağını kurarken başvurduğu montaj, alan derinliği gibi araç ve yöntemleri değerlendiren ve sinema alanında felsefe yapabilen bir kuramcı/eleştirmen olan Bazin, kendisinden sonraki araştırmacıların da ufkunu açmıştır.

Bazin, fotoğrafın ortaya çıkışıyla "plastik sanatları dış dünyayı kopyalama konusunda özgürleştirdiğini" (Bazin, 2005:12) ve psikolojik bir etki olarak tanımladığı gerçekliğe olan takıntı boyutuna varan arzumuzun fotoğraf ve sinema ile tatmin olduğunu ifade etmiştir. Bazin fotografik görüntünün ontolojisini konu alan makalesinde gerçeklikle bağlantılı temsilin ve teknik aracılığıyla değişen temsil şekillerinin de altını çizerken, konuya izleyici perspektifinden de yaklaşır. Temsilde bir soyutlama söz konusudur ve bu soyutlama sinemanın doğası ile doğrudan ilintilidir.

Bazin dışında, daha biçimci bir perspektiften yaklaşan ve tartışmaya yine kameranın işleyiş prensibiyle başlayan Rudolf Arnheim'; gerçeklik ve sinema ile ilişkili sistematik bir kuram oluşturma derdinde olan Siegfried Kracauer gibi önemli kuramcılar da konuyu ele alanlar arasındadır. Kracauer, fotoğraftan farklı olarak filmin "gerçekliği zaman içerisindeki devinimi ile temsil ettiğini ve bunu da sinemaya özgü teknik ve araçlarla yaptığı" (Kracauer, 1997:41) düşüncesi ile hareket ve zamana odaklanır.

Şurası açık ki, gündelik gerçekliği referans alma meselesi, temsili sanatların hepsinde olduğu gibi önce fotoğraf, sonra da sinemada, bu araç ve sanatların keşfinden beri çokça geri dönülen bir konudur. Bunda araçların teknolojik doğasının gerçekliği kaçınılmaz bir şekilde ve doğrudan imge yoluyla referans almasının payı çok büyüktür. Bu durumun da dışsal ve biçimsel bir yönü bulunmaktadır. İçerik boyutunda ise gerçeklik, temsilin kurulduğu filmde (ya da film türünde/filmsel anlatım biçiminde) deforme edilmek isteniyor olsa dahi referans olma özelliğini korumaktadır. Filmlerdeki herhangi bir temsilin oluşturulma sürecinde referans alınan bir gerçeklik olmalıdır ki gerek onun aslına sadık kalma kaygısı güdecek, gerekse onu soyutlayıp manipüle edebilecek yöntemler ortaya çıkabilsin.

Elbette farklı akımların, dönemlerin, eğilimlerin ve yönetmenlerin filmlerinin gerçekliğe bağlı olma dereceleri değişiklik göstermektedir. Referans gerçeklik olsa da kurmaca bir filmde bu gerçeklik temsiller aracılığıyla izleyicinin zihninde yeniden canlanacaktır. Kurmaca bir filmde, belirli anlatı kalıpları tercih edilecek, bu kalıplar eğilip bükülecek ve amaca yönelik şekillerde kullanılacaktır. Ayrıca uygun görsel-işitsel stratejilerle arzu edilen sonuçlar elde edilmeye çalışılacaktır. Bu tercihlerin tümü, sinemaya ait araçlar kullanılarak gerçeklikle bağın ne derece doğrudan olacağını da gösterir. Yaygın bir hata, belgesel filmlerin gerçekliğe en sadık filmler olduğu düşüncesidir. Oysa kameranın belli nesnelere belli bir kadrajla doğrultulduğu her an bir tercih yapilarak gerçekliğe müdahale edilmektedir. Currie'nin belgesel ve kurmacanın gerçekle ilişkisine dair ifadesiyle:

Sinemasal imgenin iki temsil işlevi vardır: Bunlardan biri fotografik diğeri ise kurmacadır. Belgesel filmler yalnızca ilkini yerine getirirken kurmaca filmler her ikisini de yerine getirir. Kurmaca bir

4 Ayrıntılı bilgi için Bkz: Rudolf Arnheim, Sanat Olarak Sinema, çev: Rabia Ünal Tamdoğan, Hil Yayınları, İstanbul: 2009. 
film de tıpk belgesel gibi, kameranın önünde olanların filme çekilmiş kaydıdır. Ancak kurmaca filmde, belgeselde olmayan şekliyle bu kayıt kurmaca bir öykünün temsili amactyla gerçekleştirilmiş bir kayıttır. Ayrımı kabaca ifade edecek olursak; belgeselin öncelikli amacı gerçeğin temsili ise, kurmaca film gerçeğin temsillerini gerçekte olmayanı ya da kurmacayı temsil etmek için kullanır (Currie, 1995:13).

Neden bazı filmler daha gerçekçi kabul edilir de bazılarının gerçeklikle kurduğu bağların daha gevşek olduğu tespit edilir? Bu filmlerde ne gibi yöntemler kullanılır? Bazin ve pek çoklarının farklı açılardan izini sürdüğü gibi alan derinliği mi? Kesintisiz, müdahalesiz çekimler mi? Anlatılanın içine yerleştirilmiş aktüel bir kamera mı? Maddi, verili gerçekliğe uygunluk mu? Gerçek mekanlara ve amatör oyunculara yer vermek mi? Zamansal olarak az müdahaleyle hayattan bir dilim sunmak mı? Gerçekliğe daha yakın ya da müdahale edilmemiş olan, sürecin içinden kendiliğinden çıkan "bulunmuş öykü"5 (the found story) müdür? Pek çok farklı cevabın verilebileceği bu soruları çoğaltmak mümkündür.

Sinemada temsil, temsil araçları ve gerçeklik ilişkisinden kısaca söz ettikten sonra, Deniz Gamze Ergüven'in çalışmanın odağını oluşturan ilk uzun metrajlı filmi Mustang'e bu çerçeveden yaklaşmaya çalışacağız.

\section{Mustang (2015)}

Mustang filminin konusunu, anne ve babaların kaybetmelerinin ardından 10 yıldır köydeki babaanne ve dayılarıyla birlikte yaşayan beş kız kardeşin taşrada karşılaştıkları baskılarla mücadele öyküsü oluşturmaktadır. Yaz tatiline giren okulunardından kız kardeşlerin hayatı, baskı altına alınmaları ve birer birer evlendirilmeye çalışılmalarıyla tamamen değişir. Film, taşra tutuculuğu, özgürlük talebi, baskı, genç kadınların cinselliği keşfi, ergenlik/kadın olmak gibi temel izlekler üzerine kuruludur.

Bu noktada, filmin yönetmeninin elindeki malzeme ile ilişkisine de biraz ışık tutabilmek amacıyla profesyonel geçmişinden kısaca söz etmek yerinde olacaktır. Deniz Gamze Ergüven Türkiye' de doğmuş, ülkeyle bağlarını sürdüren fakat yaşantısının neredeyse tamamını ve tüm eğitim hayatını Fransa'da geçiren bir sinemacıdır. Paris'teki önemli sinema okulu La Fémis'te yönetmenlik eğitimi almıştır. Kısa film çalışmalarının ardından yaptığı Mustang ilk uzun metraj filmidir. Ergüven sonrasında uluslararası projelerde yer almaya devam etmiştir.

\section{Bir Ortak Yapım Olarak Mustang}

Filmi incelerken akılda tutacağımız bir diğer unsur da filmin tamamen Türkiye'de geçen, yerli bir içeriğe sahip olduğu görünen ve Türkiyeli oyuncularla çekilmiş bir ortak yapım olduğudur. Mustang, Fransa, Almanya, Türkiye ve Katar ortak yapımı bir filmdir. Yönetmenin yapım notlarını içeren basın kitindeki röportajlarından edinilen bilgiye göre, filmin senaryosunu Cannes Cinéfoundation Atölyesi'nde tanıştığı sinemacı Alice Winocour ile birlikte yazmışlardır. Winocour Ergüven'e o dönemde yazdığı (2018 yılında gösterime giren) Kings filminin senaryosunu bir kenara bırakarak "kimseyi korkutmayacak" daha küçük

5 Sigfried Kracauer "bulunmuş öykü" tanımını "asıl fiziksel gerçeklik içinde bulunan öyküler" olarak yapmıştır. Bir nehrin yüzeyini yeterince uzun bir süre izlediğimizde görebileceğimiz hafif bir esinti ya da hareketle ortaya çıkan örüntüyü örnek verir. Bu öyküler "yaratılmaktan çok, keşfedilmiştir". Siegfried_Kracauer, Theory of Film, The Redemption of Physical Reality, Princeton University Press, USA: 1997, s 245, 246. 
bir projeyle başlangıç yapmasını önerir(Mustang Production Notes: 2015). Bu açıklamadan filmin, stratejik bir manevrayla yönetmenin ilk filmi haline geldiğini anlamak mümkündür.

Mustang' in aldığı ödüller arasında; César Awards, France - En İyi Kurgu, En İyi Orijinal Müzik, en İyi Orijinal Senaryo, En İyi İlk Film (Aynı zamanda aynı yıl en iyi sinematografi, yönetmen, film, ses ve kostüm dalında adaylıkları da var); 2015 AFI Fest (American Film Institute)- New Auteurs; 2015 Cannes F.F. (Directors' Fortnight)- Label Europa Cinemas; 2015 European Film Awards- European Discovery bulunmaktadır.

Adaylıkları ise 2016 Fransa Oscar adayı (En İyi Yabancı Film); 2016 Altın Küre adayı (Yabanc1 Dilde Enİyi Film);2015 Cannes F.F.(Golden Camera ve Queer Palm) şeklindedir(IMDb, Awards). Filmin tüm adaylıkları Fransa adınadır. İçerik ve dil tamamen Türkiyeli olsa da, bu ortak yapımın kültürel ve ekonomik sahipliğini, yönetmenin de kimliği ile birlikte Fransa'nın üstlendiği anlaşılmaktadır.

\section{Ortak Yapım Pratiklerine Nereden Bakılmalı?}

Ortak yapımlar 1980ler ve 1990lar boyunca Avrupa' da film yapımının önemli bir parçası olmuş, Avrupa sinemasında ortak yapım anlayışı özellikle 1990 sonrası sanat sinemasında neredeyse standart bir yapım şablonu haline gelmiştir. Her ortak ülke için kendi ulusal destek sistemleri dışında ek bir finans sistemi sağlamış, ayrıca sinemacıların teknik imkanlara erişimini ve kültürel ve sanatsal işbirliği inşa etmelerini kolaylaştırmayı hedeflemiştir. Öncelikle Amerikan sinemasının ülkelerindeki gösterim ve yapım payının genişliği karşısında tutunmaya çalışan Avrupa ülkeleri, Avrupa Konseyi çatısı altında Eurimages ${ }^{6}$ ve MEDIA $^{7}$ platformlarıla ortak yapım, dağıtım ve gösterim alanlarında işbirliğine gitmişlerdir. Avrupa Birliği içinde yer almasa da, Türkiye de Avrupa Konseyi'nin bir üyesi olarak ilk yıllarından itibaren bu oluşumun içindeki ülkeler arasındadır.

Gerek Eurimages, gerekse festivaller bünyesindeki ortak yapım olanakları konvansiyonel ya da yerel sınırlar dışında film yapmanın güç olduğu bu dönemlerde neredeyse alternatif birer sektöre dönüşmüş, yapım ve dağıtım mekanizmaları gibi işlemeye başlamışlardır. Bu durum özellikle 2000 sonrası yapım koşulları güçleşen Avrupa ülkeleri ve ortak yapımlar içerisinde yer alan ülkelerde daha çok film üretilebilmesini sağlamıştır. Söz konusu yıllarda dijital teknolojilerin de gelişimiyle paralel olarak film yapım koşullarına erişimin kolaylaşması, farklı ülke ortaklıklarıyla işbirliğini artırmıştır. Ayrıca ortak yapımlar ülkeleri dışında bilinmeyen ya da izleyiciye zor ulaşabilen ülke sinemalarının yapımını ve gösterimini kolaylaştırmış, izleyiciyle buluşmalarının önünü açmıştır. Bu bakımdan film yapımını canlandırma etkisinden söz etmek yanlış olmayacaktır.

Ortak yapımlarla ilgili bir diğer konu da öncelikle birden fazla ülkede (en azından ortak yapıma dahil ülkelerde) gösterime girme şansının yanı sıra festivallerdeki dolaşım ve görünürlüğün artmasıdır. Filmlerin sahipliği ulusal sınırları daha yapımın en başından aştığı için filmler yollarına ulusal sınırların dışında başlamakta, uluslararası festivallerin de katkısıyla görünürlük ve dolaşım artmaktadır.

Öte yandan sağladığı birçok olumlu katkıyla, aksi halde mümkün olmayacak filmlerin

6 Ayrıntılı bilgi için bkz: Eurimages, About Eurimages: European Cinema Support Fund, https://www.coe.int/ en/web/eurimages/about

7 Ayrıntılı bilgi için bkz: MEDIA Overview: Supporting and promoting Europe's audiovisual sector, https:// ec.europa.eu/programmes/creative-europe/media_en 
üretimini yıllardır mümkün kılan, sanat sinemasını destekleyen ortak yapım anlayışı, sinemacıları (festivallerle birlikte) belirli trendlere ve sinemasal karar alma mekanizmalarında kimi yerleşik reflekslere yönelttiği yönünde eleştirilmektedir. Festivallerin de etkisiyle yıllar içinde ülkelere göre beklentiler oluşmuş, yapım ve dağıtım şirketlerinin ülkelere ve dönemlere göre değişen kotaları ortaya çıkmış ve hepsi birbiriyle ilişkili gelişen, ekonomik boyutu göz ardı edilemeyecek karmaşık bir düzen oluşturmuştur. Sinemanın finansal boyutunun, zaten kolay olmayan (konvansiyonel sinema dışı) film yapma çabasını riskin düşük tutulacağı yapımlara, dolayısıyla da kabul gören eğilimlere yönelttiği gözlemlenebilmektedir.

Daha önce de belirttiğimiz gibi, neyin Avrupalı olduğu, hangi filmin, hangi ülkenin filmi olduğu meseleleri günümüzde eskisinden de daha karmaşıktır. Filmlerin finansal mı, kültürel mi, yoksa içeriğe bağlı mı tanımlanacağı sorularının tek bir cevabı yoktur. Sahiplik ve ulusal kimlik konusunda Thomas Elsaesser şu tespitlerde bulunmuştur:

Ulus sineması denen şeyin Avrupa sınırları dahilinde eridiği görülebilmektedir. Kieslowski'nin Üç Renk üçlemesindeki Mavi filmi Fransa, Polonya, İsviçre ortak yapıml; filmin yönetmeni Polonyah ve başrol kahramanı Fransiz. Bu filme tek başına Fransız demek doğru mu? Chocolat filmi Fransa'da geçer, yönetmeni İsveçlidir ve bir İngiliz-Amerikan ortak yapımıdır. Şimdi buna ne filmi diyeceğiz? İzleyici için kriter farklı olabilir. Juliette Binoche'u filmin yıldızı olarak görüp bu filmleri Fransız filmi olarak düşünebilir. Sinefiller ise yönetmeni tanıyacağı için, dilsel ya da mekânsal bir bă̆ olmasa da filmi onun ulusal kimliği ile bă̆daştırabilir. (Elsaesser, 2005: 75,76).

Bir diğer yorum da, filmlerdeki etnik bakış ve ortak yapım stratejilerinin ortaya çıkarabileceği oryantalist eğilimler üzerinedir. Çünkü uzak bir yerel içerikle yapılan filmler, gösterildiği toplumlara, o uzak yerelliğe ilişkin bilgi vermektedir. Filmler aracılığıyla öğrenilen yaşantı parçası gerçeğin yerini almakta; böylece İtalyan bir izleyici, Romanya hakkında filmde verilen bilgiler üzerinden bir fikir sahibi olmaktadır. Randall Halle'nin ifadesiyle;

Avrupa değerleri perspektifinden filmler izleyiciye o yabancı toplum üzerine eleştirel müdahale hakkı sağlar. Böylece ortak yapım stratejisi Avrupalı ve Amerikalı izleyicilere kendilerinden tamamen farklı insanlar hakkında duymak istedikleri masalları anlatarak ve onları köşe başında ya da koridorun sonunda yaşayan uzak yabancılar olarak tutarak bir oryantalizm döngüsü kurma riskini taşır(Halle, 2010:304).

Bu yorumuna ek olarak Halle, Avrupa ortak yapım fonları özelinde oryantalizmin dört işleyiş şeklini tespit etmiştir;

(1) Yerel film endüstrilerinde kriz olan bölgelere geliştirme desteği götüren Avrupa fonlarn; (2) ardından gelen, geliştirme politikalarındaki kültürü kendine mal etme şeklindeki acayiplik; (3) bu filmlerin yerli filmlerin başka türlü yapamayacağı bir şekilde yerel kültüre eleştiri getirmesi; bununla birlikte (4) Avrupa fonlarının bölgesel bir birlik yerine farklllı̆̆ üretmesi ve düşünce ayrilıkların desteklemesi.

Temel olarak, ortak yapım filmlerin Avrupa ve Kuzey Amerika izleyicisini cezbedecek öyküler sunabilmesi gereklidir(Halle, 2010: 317). 


\section{Filme tepkiler}

Filme dünyadan ve Türkiye'den gelen eleştiriler iki yönlü olmuştur. Cannes'daki gösteriminin ardından film, kadın öykülerini kararlılıkla anlatıyor olması ve anlatım biçimine ilişkin olumlu eleştiriler almıştır. Bu olumlu eleştirilerin büyük bir bölümü yabancı basında yer almaktadır. ${ }^{8}$ Öte yandan film Türkiye' de tam olarak aynı coşkuyla karşılanmamıştır.

Türkiye kırsalında yaşanan olaylara çok dışarıdan bir bakış açısıyla9 yaklaştığı konusunda eleştiriler alırken Ergüven, birçok röportajında Türkiye'deki baskıdan ve filme de yansıyan geleneklerden söz etmiş, filmin "anayurdu üzerine kapsamlı bir yargı değil, kendi deneyiminin kurmacayla karıştırılmış kişisel bir sanatsal yorumu" (Weston, 29.12.2015) olduğunu belirtmiştir.

Genç kadın bedenlerinin filmdeki sergilenişinin istismara açı bir alan oluşturması da filme yöneltilen olumsuz eleştirilerden olmuştur. Bir röportajında yönetmene, söz konusu sahneler düşünüldüğünde ve filmin içeriğinin tamamen Türkiyeli olmasına rağmen Fransa'nın yabancı dilde Oscar adayı olması konusunda Türk izleyicinin düşüncesine ilişkin yorumu sorulduğunda buna şöyle bir açıklama getirmiştir:

Film Türkiye'de çok saldır ve kutuplaşmayla karşılandı ve eleştiri de filmin içeriği üzerinden ifade buldu. İnsanlar bu kızlarm bedenlerini görüyor ve nasıl bu kadar sergileyebildiğimizi soruyor. Buna cevabım; eğer onlara çocuk olarak bakmış olsaydınız belki de böyle görmezdiniz (O'Grady, 18.02.2016).

Yönetmenin verdiği röportajlarda filmin Türkiye izleyicisi tarafından yanlış alımlandığına ilişkin yorumlar yer almaktadır. Yönetmenin ifadelerinden, niyet ve sinemasal temsil kurma biçimi (özellikle de öykünün kuruluşu anlamında) ile ortaya çıkan sonuç olan söylem arasında uyumsuzluklar olduğu anlaşılmaktadır.

\section{Mustang'de Temsil Sorunları}

Mustang filminde yer alan temsilleri incelemek için öncelikle filmin ele aldığı konuyla kurduğu ilişkiyi değerlendirmek gereklidir. Filmdeki belli başlı temsiller içinde kadın olmak, taşra zihniyeti ve özgürlük talebi odağı oluşturmaktadır. Bu temsiller sinemasal araçlarla kurulurken ortaya çıkmış belli sorunlar tespit edilmiştir. Bunlar gerçeklik ve temsil ilişkisi bağlamında inandırıcılıktan uzak olma sorunu, temsilin anlatısal araçları bağlamında tutarsızlık ve dışarıdan bakış/etnikleştirme olarak sıralanabilir. Şimdi bunlara biraz daha yakından, filmden örneklerle bakalım:

8 Film hakkında yazılan bazı eleştiriler için; Jay Weissberg (19.05.2015), Film Review: Mustang, https://variety. com/2015/film/festivals/mustang-review-cannes-1201500486/

Fabienne Lemercier (19.05.2015), Mustang: Five Girls and the Fate of Women, https://cineuropa.org/en/ newsdetail/292998/

Hillary Weston (29.12.2015), Deniz Gamze Ergüven on Her Feminist Fable Mustang

https://www.criterion.com/current/posts/3852-deniz-gamze-erg-ven-on-her-feminist-fable-mustang

9 Ali Ercivan'ın eleştirisine bakılabilir. http://www.beyazperde.com/filmler/film-228825/elestiriler-beyazperde/ 


\section{Gerçeklik ve temsil ilişkisi bağlamında inandırıcılıktan uzak olma}

İlk sorun, Mustang filminin kurduğu öykü evreninin gerçekliğe uymaması şeklinde karşımıza çıkmaktadır. Yönetmenin de (böyle eleştirilmemesi gerektiği düşüncesiyle) dikkati çektiği üzere, doğrudan içerikle ilintili bir sorundur. Filmin geçtiği öykü evreninin tam olarak Türkiye' nin neresine denk düştüğü filmde ifade bulmasa bile, coğrafyayı az çok bilen izleyici için inandırıcılık tehlikeye girmektedir. Çünkü yönetmenin anlattığı öyküyü gerçek mekan ve zamandan doğrudan soyutlayan, izleyici tarafından kabul edilebilecek bir yaklaşımı yoktur. Genç kızların yetiştikleri coğrafya, geldikleri yerle olan ilişkileri, sahip oldukları nesneler ve eşyalar, bulundukları yerdeki davranış kalıpları vb. ile Türkiye ve söz konusu bölge hakkında fikir sahibi olan izleyiciyi ikna etmekten uzaktır.

İnandırıcılık sorununa bazı örnekler verecek olursak; film bir Ege sayfiyesinde olduğumuzu düşündürebilecek sahnelerle açılır; fakat birden her şey değişir. Filmde henüz hiç bir bilgi sahibi değilken ilk gördügüumüz şey, okullarının son gününde, herhangi bir şehir ya da sayfiyede olabilecek kadar rahat ve modern görünen okul formalı beş kız kardeştir. En küçükleri olan Lale İstanbul'a tayini çıkan öğretmeninden ayrılacağı için üzülmektedir. $\mathrm{Bu}$ sahneyi denizde kızlı erkekli oynanan bir deve güreşi oyunu izler. İşte bundan sonra izleyicinin içine atıldığı öykü evreni, eldeki verilerle yan yana koyulduğunda inandırıcıllı̆ııı kaybetmektedir. Taşranın dedikodu mekanizması çalışmıştır ve bu olayın ardından beş kardeş, yaz tatilini fırsat bilen babaanneleri ve dayıları tarafından eve kapatılırlar.

Hastanede yaptırılan bekaret kontrolünün ardından kardeşlerin dış hayattan soyutlanma sürecinin babaanneleri tarafından tüm modern giysilerine, telefon, makyaj malzemesi, kartpostallar, dergiler gibi her türden eşyalarına el konması ile başlar. Bu noktada anlaşılmaz olan şey; bu genç kızlar yaşamlarının son 10 yılını söz konusu kasabada geçirmişlerse (bu durumda özellikle Lale' nin neredeyse başka bir yaşantısı olmamış olmalı) yırtık- kısa kot şortlar, üzerinde DİREN GEZİ yazan t-shirtler gibi nesneleri nasıl edindikleridir. İzleyiciden her şeyi birdenbire değiştiren bir olay olarak verilen denizde erkek öğrencilerle eğlence sahnesi öncesinde bu kardeşlerin nasıl bir yaşantıları olduğunu düşünmesi beklenmektedir? Objektif bir bakış açısıyla görülen, kardeşlerin yakın tarihli bir kent yaşantısına sahip olabilecekleridir. Fakat filmde verilen bilgiler bunun tersini söylemektedir. Bu noktada, hem filmin ana odağını oluşturan karakterler hem de içinde bulundukları evrenin filmsel olarak tanımlanması konusunda gerçeklik ve temsil ilişkisinin sorunlu olduğu görülmektedir.

Daha sonra filmde kardeşlere komşu kadınlar tarafından elbirliğiyle verilen yemek ve ev işlerine ilişkin kurslar ve bilgileri içeren sekans adeta bir yemek atölyesindelermiş gibi kurgulanmıştır. Ard arda eklenen yemek yapma planlarının dinamiği, oyuncul, keyifli bir kurguda sunulmuştur. Öyle ki, komşu teyze söze bir televizyon sunucusu gibi “şimdi çorbalar hakkında genel bilgi veriyorum" diye başlayabilmektedir. O köy ya da kasabada yaşıyor olduğunu kabul edebileceğimiz bir yan karakter, kendisinden beklenmeyecek şekilde, kitabi bilgiler anlatan bir aşçlık hocasına dönüştürülmüştür.

Kızlar için dikilen kahverengi tonlarda tekdüze elbiseler ise sembolik bir anlam yaratmak üzere öyküye dahil edilmiş olduğu izlenimi yaratmaktadır. Dikkat çekmemeleri amacıyla yapılmış olduğu anlaşılan; üzerlerindeki baskıyı vurgulayan bir öyküsel tercihtir. Fakat genç ya da yaşlı kimsenin öyle giyinmediği bir yerde onları tek tip giyinmeye zorlamak, gerçeklikle kurulan bağa başka bir sorunlu örnektir. Bu kostümlerin, ancak orada yaşayan topluluk böyle giyinse ve topluluğa uymaları için bir baskı mekanizması olsa, anlaşılabilir bir tarafı olabilir. 


\section{Temsilin anlatısal araçları bağlamında tutarsızlık}

Konusu itibarıyla kadınlar üzerine önemli şeyler söylemeyi amaçlayan, belli sorunlara dikkat çekmek isteyen bir film olarak Mustang filminde o kadar çok öyküsel unsur arka arkaya sıralanmıştır ki, bu durum neredeyse konuyu karikatürize etme noktasına ulaşmaktadır. Böyle olunca da, aslında tek başlarına etkili olabilecek olaylar ve sembollerin etkilerini kaybettikleri görülmektedir. Filmin esas meselesi, uzun yeleli yaban atları ile özdeşleştirilen bu genç kızların sergiledikleri serbest davranışlar nedeniyle ıslah edilmeye çalışılarak baskı görmeleridir. Ancak buna ulaşmak amacıyla filmde o kadar çok anektod sunulur ki, anlatıda dağınıklık tutarsızlığa sebep olur.

Filmin olay örgüsünde de tıpkı görüntü yönetimi tercihlerinde olduğu gibi hiç bitmeyen bir devinim vardır. Öyle ki, baskı aracı olarak görülebilecek her türlü olay ve gösterge filmin olay örgüsünün içine tıkıştırılmış gibidir. Bunu olumsuz bir ortak yapım refleksi olarak uluslararası izleyici tarafından anlaşılamama korkusu olarak değerlendirmek de mümkün olabilir. Olay örgüsüne dahil tüm bu olaylar, kadına yönelik cinsiyet kalıplarına ilişkin unsurlardır ve bu kadar kısa bir sürede bu beş kız kardeşin başına gelemeyecek kadar çoktur.

Dedikodu, bekâret kontrolü, zorla evlendirmeler, kadının ait olduğu düşünülen domestik cinsiyet kalıplarına sokulmaları, dayılarından gelen aile içi cinsel istismar, her şey o günleri beklemiş gibi arka arkaya meydana gelmektedir. Hatta bu durumun abartılı bir hal aldığı, daha önce baskıya ilişkin hiç bir gösterge yokken (sanki kızlar orada yaşamıyorlarmış gibi) eve kilitleme, tüm nesnelere el koyma, tek tip giysiler giymeye zorlanma gibi keskin değişimlerle gösterildiği görülmektedir.

Film ilerledikçe kardeşlerin yaşadığı olaylar tutarsız ve şaşırtıcı bir tonda sürmektedir. Kendisine ilan-ı aşk eden sevgisiyle kaçarak buluşan Sonay' öyküye eklendiği düşünülebilir. Diğer yanda ise babaannenin bilgisi (bilip susmak) dahilinde dayısının cinsel tacizine uğrayan, fakat pazaryerinde tanımadığı bir gençle düşünmeden arabada sevişebilen Ece'nin isyanını bir neden-sonuç düzlemine oturtmak kolay değildir. En küçükleri olan Lale'nin okul kitabında okuduğu bölümün "Hak ve Özgürlükler" başlıklı ünite olması; hep birlikte televizyonda izledikleri bir sohbet programında kadın hal ve hareketleriyle ilgili muhafazakar söylemlerin duyulması; kızların evden kaçıp gitmeyi planladıkları maçın stadyumda şiddet nedeniyle ceza verilmiş ve sadece kadın ve çocukların katılabileceği bir maç olması şeklinde arka arkaya olay örgüsüne eklenmiş anekdot ve olaylar bir göstergeler yığını oluşturmaktadır.

Taşradaki (fakat köy mü yoksa kasaba mı olduğu belirsizdir) ataerkil baskıya ve tutucu bakış açısına ilişkin unsurlar arasında, genç kızların (özellikle de en küçükleri olan Lale' nin) kendine destek olarak gördüğ̈ü, kardeşleri kaçırdıkları maç minibüsüne yetiştiren ve Lale'ye araba kullanmayı öğreten manav Yasin'e yönelik bir ifade de yer alır. Ona ulaşabilmek için manav poşetlerinin üzerindeki telefon numaralarını arayan Lale, Adını bilmediği için Yasin'i uzun saçlarıyla tarif eder. Telefondaki esnaftan gelen cevap ise "bizde ibne satıcı yok" şeklindedir. Taşraya her türlü tutuculuk yerleştirilmiştir. Ayrıca kentte erkek-kadın ilişkilerinin baskıcı ve evlilik üzerinden kurgulanış biçimine tezat olarak; filmin finalinde İstanbul'a ulaşan Lale ve Nur'un adresinden evini buldukları öğretmenleri erkek arkadaşıyla yaşamaktadır. Bu da filmde başından beri kurulan tutucu taşra temsilini özgür metropole ulaştırarak abartılı bir kıyas ortaya koymaktadır. 
Filmde fiziksel gerçeklikle bağların sıkı kurulu göründüğü, görsel ya da anlatısal tercihlerle de bunun aksi ima edilmediği için filmi yönetmenin röportajlarında belirttiği gibi Türkiye'nin gerçekliğini kurmaca ile karıştırarak yansıtan bir "peri masalı"(Weston, 29.12.2015) olduğu ön kabulü ile izlememiz beklenemez. Dolayısıyla izleyici gerçeklikle temsil boyutundaki referansları tutarlı bir şekilde ya doğrudan bağlantılı şekilde kurulmuş bir film görmeyi beklemektedir. Ayrıca bunun olay örgüsü kuruluşunda tutarlı bir dizgede verilmesi beklenir. Bir filmde aynı anda hem gerçeklikle gevşek bağlantılara yer verildiği iddiasını taşımak hem de toplumsal gerçeklerin aynası olmaya çalışmak, filmde tutarsız temsil stratejileri kullanıldığını göstermektedir.

\section{Dışarıdan bakış - etnikleştirme}

Özellikle 1990 sonrası Türkiye sinemasında taşrayı mekan edinen filmlerin bu mekan tercihlerini pek çok farklı gerekçelerle yaptıklarını görmek mümkündür. Zamanın ağır aktığı, doğanın döngüsünün zamanı ve gündelik yaşamı belirlediği, metropolün ve büyük kentlerin değerlerinin geçerli olmadığı mekanlar olarak yansıtılan taşra kasaba ve köylerine bir nevi nostaljiyle ve geri dönüş öyküleri üzerinden sıklıkla yaklaşılmıştır. Bu durumu Nuri Bilge Ceylan, Semih Kaplanoğlu, Yeşim Ustaoğlu, Reha Erdem, Özcan Alper gibi yönetmenlerin yanı sıra Çağan Irmak, Yılmaz Erdoğan, Mahsun Kırmızıgül ve Sermiyan Midyat gibi ana akım yönetmenlerin filmlerinde de görebilmekteyiz. Fakat taşra yaşantısı, üzerindeki nostalji halesi dışında tutuculuk, ikiyüzlülük ve gelişime kapalı olma gibi özelliklerle de bir arada anılmaktadır. Tanıl Bora Taşralaşmamak ve Taşra' yı Yitirmemek başlıklı yazısında şöyle açılar:

Taşrayı sıfat anlamının olumsuz çağrışımlarıyla aldığımızda, sahiden, Türkiye'nin taşralı yüzüyle karşılaşmamak zordur: Dar ufuklar, kahredici bir yeknesaklık, boğucu bir taassup, iletişim eoreninin - teknolojiyle daha da derinleşebilen- kısıtlıllğ̆1, cemaatlere sıkışmış kısır bir kamu alem, yabancı olan her şeyi tuhaf bir bitkiymiş gibi algılayan "yabani" bir hal, vasatlı̆̆ın hizaya sokucu egemenliği...(Bora, 2010: 168)

Mustang'de gerçeklikle bağın gevşekliği düşüncesine sığınılarak yer verilen birçok dışarıdan bakış örneği görülmektedir. Öncelikle, Ömer Türkeş'in edebiyatta sözünü ettiği taşra düşüncesini tek bir kalıba sokarak genelleştirme ve aynılaştırma durumu Mustang'de de söz konusudur.

Türk romanında Anadolu'ya taşra olarak bakan ama hep bir dişarıdanlıkla bakan göz, işte bu entelektüelin gözüdür. Bu öyle bir gözdür ki, kendisini daha yola koyulduğunda ele verecek; "zencileri", "kırmızı" ya da "sarlları" birbirinden ayırt etmeyen, etmek istemeyen oryantalist seyyahlar gibi taşranın bütün kent, kasaba ve köylerini, bütün insanların ve bütün hayatların aynılaştıracaktır.(Türkeş, 2005: 162,163)

Türkeş'in ifadeleri Mustang için de geçerlidir. Filmdeki taşra hangi taşradır? Nerenin taşrasıdır? Türkiye'de taşra olarak adlandırılabilecek bütün bölgeler birbirinin aynı mıdır? Bunu besleyen öykü unsurları kurulan karikatürize karşıtlıklar ve dedikoducu komşular, gelenekler, kız istemeye her an hazır aileler gibi klişelerdir. Filmde klişelere başvurmak her zaman olumsuz bir çağrışım taşımaz. Daha önce de ifade edildiği gibi, klişeler sinemasal öykü anlatımında zaman kazandırır ve belli ölçülerde gereklidirler. Fakat burada önem taşıyan unsurlar klişelere yaklaşım, bakış açısı ve bu bakış açısındaki tutarlılıktır. 
Filmde anlatılmak istenenin Türkiye' nin taşrasındaki beş kız kardeşin baskı nedeniyle başlarına gelenler ve özgürleşme mücadeleleri olduğu açıktır. Bu beş kardeşin orada 10 yıldır yaşadığı filmdeki bir diyalog aracılığıyla izleyiciye aktarılmakta iken; kızlar İstanbul'dan, hatta biraz abartılırsa Fransa' dan bir gün önce oraya gönderilmiş gibi davranan karakterlerdir. Temel odağı oluşturan kardeşler dışında, filmde betimlenen babaanne karakteri de hem despottur hem de değildir; hem köylülerden biridir hem de davranış kalıpları, konuşması ve beden diline bakılacak olursa oldukça şehirli görünmektedir. Bu özelliklerinin tespitiyle karakterler yaşayan, sahici karakterler olmaktan uzaklaşırlar. Filmde göstergeler birbirine karışmış gibidir ve coğrafyaya dair biraz fikri olan herhangi birinin mevcut sorunları görememesi mümkün değildir.

Yönetmenin anlattığı malzemeye etnik, yerel bir unsur gibi yaklaşması onu anlatıda manipüle etmesine, etnikleştirmesine, hatta oryantalist bakışın sularına girmesine sebep olmaktadır.

Bu noktada, David Martin-Jones'un aktarımıla, Mary Louise Pratt tarafından açıklanan haliyle oto-etnografi (autoethnography) kavramından söz etmek yararlı olabilir. Kolonileşmiş kültürlere içkin bir tavır olarak tanımlanan oto-etnografi, tıpkı turistik eşyalar gibi "hem kültürün otantik bir ürünü hem de bir turistin o ülkeye ait etnik ürün dendiğinde aklında canlanacak nesneler" (Martin-Jones, 2010: 16) örneğiyle açıklanmıştır. Bunun sinemadaki karşılığı da, yönetmenlerin uluslararası izleyiciye görmek istediklerini vererek stereotip imgelerle ele aldıkları kendi kültür ya da toplumlarını egzotikleştirmesi olarak ortaya çıkmaktadır.

Oto-etnografi aynı zamanda araştırmacının kendine ve kendi gibi olana bakmasından yola çıkan antropolojik bir araştırma yöntemidir ve bakış açısının berraklığ1 (daha doğru bir deyişle güvenilirliği) konusunda tartışmalar doğurmuştur. ${ }^{10}$ Pratt'a göre "Oto-etnografik metinler alımlanma bakımından da heterojendir; çünkü hem kentli okuyucuyu hem de anlatıcının kendi toplumsal grubu içinde eğitimli kesimleri hedef alır ve her biri tarafından da ayrı şekilde karşılanır" (Pratt, 1992: 7). Filme ilişkin tartışmalarımızın bir boyutunu da 'kim tarafından' ve 'kimin için' soruları oluşturduğundan; filme Türkiye' den ve Türkiye dişından gelen tepkileri Pratt'in toplumsal grup içi ve dışı örneğine benzetebiliriz.

Filmde yer alan temsil sorunlarının tümüne verilebilecek en iyi örneklerden birini Sonay ve Selma'nın evlendirildiği çifte dügüun sahnesi oluşturmaktadır. Bu sahnede, sözünü ettiğimiz inandırıcılık sorunu, tutarsızlık ve etnikleştiren/oto-etnografik bakışın hepsi birden yer almaktadır. Filmde bir yandan kına gecesi, gelin alma, düğün konvoyu, "kız evi naz evi" diyerek çeyiz sandığının üzerine oturma, havaya silah sıkma gibi geleneksel kabul edilen pratiklere yer verilirken, diğer yandan da düğün eğlencesinde Alevi semahıyla göbek atılmaktadır. İzleyicinin adeta bir gelenek kolajı ile karşı karşıya bırakıldı̆̆ı bu sahnede göstergelerin karıştırıldığı, Aleviliğe ait, kendi içerisinde özel anlamlar ve referanslar taşıyan bu geleneksel müzikle, insanların dans ettiği eğlence müziğinin birbirinin yerine kullanıldığ1 görülmektedir.

Sahnenin devamında gösterge karmaşası devam etmektedir. 'Geleneksel' olduğu vurgulanan bu dügünnde zaten daha önceden sevgili olan yeni evli çift Sonay ve Ekin' in tutucu

10 Ayrıntılı bilgi için bkz: Carolyn Ellis, Tony E. Adams and Arthur P. Bochner, Autoethnography: An Overview, Historical Social Research / Historische Sozialforschung, Vol. 36, No. 4 (138),Conventions and Institutions from a Historical Perspective / Konventionen undInstitutionen in historischer Perspektive (2011), pp. 273-290. 
kasaba (ya da köy) sakinlerinin arasında sarılarak birbirlerinin yüzünü ve boynunu öpmeleri izleyiciyi gerçeklikten bir kez daha, bu sefer başka bir seviyede koparmaktadır. Bu sahnede geleneksellik, tutuculuk, davranış kalıplarının sınırı gibi konulara yaklaşımda tutarsızlıkla birlikte etnikleştirme kol koladır.

Öte yandan filmde genç kızların bir arada olduğu, birlikte zaman öldürdükleri, tembellik yaptıkları, şakalaştıkları ve eğlendikleri sahnelere özel bir estetik yer ayrıldığı görülmektedir. Bunlar içerisinde durağan, adeta tablo gibi tefekkür planları yer aldığ1 gibi, filmde çoğunlukla kullanılan aktüel, karakterleri takip eden hareketli kamera ile dinamik bir şekilde görüntülendikleri sahneler de söz konusudur. Durağan ya da canlı olsun bu sahnelerin, rüya gibi, masalsı bir yanı vardır. Bu sahnelerde kardeşler adeta beş başlı, tek vücutlu mitolojik bir varlık haline gelirler. Filmin geneliyle doku farklılı̆̆ taşımakla birlikte, bu sahneler için yapılan genç bedenleri sergileme, nesneleştirme eleştirisinde olduğu gibi bir işleve sahip olduklarını iddia etmek zorlama olacaktır. Denizde erkek öğrencilerle deve güreşi yaptıkları sahne, birbirleriyle şakalaştıkları sahneler, babaannelerinin onları giymeye zorladığı çirkin elbiselerinden onları keserek kurtuldukları sahne, maçtaki coşkularını gösteren sahneler; eve kapatıldıkları güneşli günlerde mayo giyerek güneşlendikleri sahneler gibi kendi içlerinde bir doğallıkla çekilmiş örnekler gösterilebilir.

\section{Sonuç: Kim, Kimin Temsilini Kuruyor? Film Ne Söylüyor?}

Ortak yapımlar çerçevesinde bugün kabul edilmesi gereken bir gerçek de, bir çok filmin sahipliğinin karmaşık bir hal aldığı ve bundan sonra da böyle olacağıdır. Çünkü ortak yapım şeması, konvansiyonel sinema dışında üretim yapan birçok sinemacı için önemli bir prodüksiyon yöntemi olmaya devam etmektedir. Sahiplik meselesinin kültürel boyutunda karşılaşılacak en önemli sorunlar da filmsel temsiller alanında tartışılmaya devam edecektir.

Konuya filmdeki temsillerin mimarı Deniz Gamze Ergüven (ve elbette filmin diğer senaristi Alice Winocour) çerçevesinde yaklaşılacak olursa, yönetmenin etnik kökeninin de etkisi ile çift kültürel kimlikli bir yaklaşıma sahip olduğu anlaşılmaktadır. Bu yaklaşım belli bir mesafe aracılığıyla gerçekleşen net bir bakıştan çok; Türkiye' de geçen, odağını Türkiye' de yaşananların oluşturduğu, Türkiye'den aktörlerle ve Türkçe çekilen bir Fransız filmi ortaya çıkarmıştır. Bu noktada, ele aldığı konuya bakış açısının hassasiyeti ortaya çıkardığı söylemdeki pek çok hususun belirleyicisi olmuştur. Filmin özgürlükçü söylemi yönetmenin başvurduğu tercihlerle ortaya koyulmaya çalışılırken, bu çalışmada dikkat çekilen temsil sorunlarının ortaya çıan nihai anlamı, filmin söylemini olumsuz yönde beslediği görülmektedir.

Filmin finalinde, Lale ve Nur, Boğaziçi Köprüsü'nü geçerek İstanbul'a ulaşırlar ve Lale' nin tayini İstanbul'a çıkan öğretmenini bulurlar. Filmin finalinin birçok düzlemde önemi vardır. Köprüyü geçip, Asya kıtasından Avrupa'ya geçiş yapan kardeşlerin yüzleri yansıyan gün 1şığı ile aydınlanır. Film tektipleştirdiği taşra kavramının karşısına açıkça İstanbul'u, Anadolu'nun karşısına ise Avrupa'yı koymaktadır. Buradan anlaşılması beklenen taşranın hapis ve baskı, İstanbul'un kurtuluş ve özgürlük anlamına geldiği midir? Film gerçekçi referanslarla örülü olduğu halde -Boğaziçi köprüsü pek çok izleyici için doğrudan bir referanstır- genelleştirilebilecek bir gerçeklikten uzak bir söyleme varmaktadır.

$\mathrm{Bu}$ durumda, filmde temsil edilenlere ilişkin hem evet hem de hayır cevabı verebileceğimiz birçok soru gündeme gelmektedir: Temsil edilen kimdir? Taşra çeperinde 
kısılan genç kardeşler midir? Peki, böyle bir taşra var mıdır? Bu genç kardeşlerin karşılaştığ1 baskının dönemin Türkiye'sinde gerçeklik payı var mıdır? Filmdeki karakterler ve olaylar gerçeklikle bağlantılı mıdır? Tüm bu sorulara verilebilecek cevap hem evet hem de hayırdır. Deniz Gamze Ergüven'in, gerek gerçeklikle ilişkisi, gerekse bu ilişkiyi ortaya koyacak filmsel tercihlerinde ortak yapımların eleştirildikleri klasik tuzaklara düştüğü ve etnikleştiren bir bakış açısına saplanarak tutarsız ve sorunlu bir söylem ortaya koyduğu görülmektedir.

\section{Kaynakça}

\section{Kitaplar:}

ARISTOTELES (2012), Poetika, çev. İsmail Tunalı, Remzi Kitabevi: İstanbul.

ARNHEIM, R. (2009), Sanat Olarak Sinema, çev: Rabia Ünal Tamdoğan, İstanbul: Hil Yayınları.

BAZIN, A. (2005), The Ontology of the Photographic Image", içinde What is Cinema?, Cilt 1, ABD: California University Press.

BENJAMIN, W. (2008), Tekniğin Olanaklarıyla Yeniden Üretilebildiği Çağda Sanat Yapıtı, içinde Pasajlar, İstanbul: Yapı Kredi Yayınları.

BORA, T. (2010), Taşralaşmamak ve Taşrayı Yitirmemek, Z. T. AKBAL SÜALP içinde, Taşrada Var Bir Zaman (s. 167-183) Ankara: Çitlembik Yayınları.

CARROLL, N. (2012.), Sanat Felsefesi: Çă̆daş Bir Giriş, çev: Güliz Korkmaz Tirkeş, Ankara: Ütopya Yayınevi.

CASEBIER, A. (1991), Film and Phenomenology, Towards a Realist Theory of Cinematic Representation, New York: Cambridge University Press.

CHATMAN, S. (2008), Öykü ve Söylem: Filmde ve Kurmacada Anlatı Yapısı, çev: Özgür Yaren, Ankara: De Ki Basım Yayım.

CURRIE, G. (1995), Image and Mind, Film, Philosophy and Cognitive Science, Australia: Cambridge University Press.

ELSAESSER, T. (2005), European Cinema, Face to Face with Hollywood, Amsterdam: Amsterdam University Press.

HALL, S. (1997), The Work of Representation, S. HALL içinde, Representation, Cultural Representations and Signifying Practices (s.13-75), London: Sage Publications \& Open University.

HALLE, R. (2010), Offering Tales They Want to Hear: Transnational European Film Funding as Neo-Orientalism, R. GALT ve K. SCHOONOVER içinde, Global Art Cinema, New Theories and Histories, (s. 303-320) New York: Oxford University Press.

KRACAUER, S. (1997), Theory of Film, The Redemption of Physical Reality, ABD: Princeton University Press.

MARTIN-JONES, D. (2010), Scotland: Global Cinema- Genres, Modes and Identities, England: Edinburgh University Press. 
METZ, C. (2012), Sinemada Anlam Üstüne Denemeler, çev: Ŏguz Adanır, İstanbul: Hayalperest Yaymevi.

PRATT, M. L. (1992), Imperial Eyes: Travel Writing and Transculturation, London: Routledge.

TÜRKEŞ, Ö. (2005), Orda Bir Taşra Var Uzakta, T. BORA içinde, Taşraya Bakmak (s. 157213) İstanbul: İletişim Yayınları.

\section{Makaleler:}

ELLIS, C ve E. ADAMS, A. P. BOCHNER (2011), Autoethnography: An Overview, Historical Social Research / Historische Sozialforschung, Vol. 36, No. 4 (138),Conventions and Institutions from a Historical Perspective / Konventionen undInstitutionen in historischer Perspektive, Cologne: GESIS - Leibniz Institute for the Social Sciences.

\section{İnternet Kaynaklari:}

ERCIVAN, A. (tarih belirtilmemiş), 20.01.2019 tarihinde http://www.beyazperde. com/filmler/film-228825/elestiriler-beyazperde/ adresinden alınd1.

Eurimages, (yıl belirtilmemiş) About Eurimages: European Cinema Support Fund, 20.01.2019 tarihinde https:// www.coe.int/en/web/eurimages/about adresinden alınd1.

IMDb, (yıl belirtilmemiş) Mustang Awards, 20.01.2019 tarihinde

https://www.imdb.com/title/tt3966404/awards?ref =tt awd adresinden alınd1.

MEDIA, (yıl belirtilmemiş) MEDIA Overview: Supporting and promoting Europe's audiovisual sector, 29.04.2019 tarihinde https://ec.europa.eu/programmes/creative-europe/ media en adresinden alınd.

Mustang Production Notes (2015) 20.01.2019 tarihinde https://curzonblob.blob.core. windows.net/media/5081/mustang-production-notes.pdf adresinden alınd1.

LEMERCIER, F. (19.05.2015), Mustang: Five Girls and the Fate of Women, 20.01ç2019 tarihinde https://cineuropa.org/en/newsdetail/292998/ aresinden alınd1.

O'GRADY, S. (18.02.2016), An FP Conversation: Love, Sex, and Growing Up in a Regressive Turkey, 20.01.2019 tarihinde https://foreignpolicy.com/2016/02/18/an-fp-conversationlove-sex-and-growing-up-in-a-regressive-turkey/ adresinden alınd1.

WEISSBERG, J. (19.05.2015), Film Review: Mustang, 20.12.2019 tarihinde

https://variety.com/2015/film/festivals/mustang-review-cannes-1201500486/ adresinden alındi.

WESTON, H. (29.12.2015), Deniz Gamze Ergüven on Her Feminist Fable Mustang, 20.01.2019 tarihinde

https://www.criterion.com/current/posts/3852-deniz-gamze-erg-ven-on-herfeminist-fable-mustang adresinden alındı. 